\title{
Growth Characteristics of the Yeast Phase of Paracoccidioides brasiliensis in a Chemically Defined Medium
}

\author{
By KARIN L. MCGOWAN AND HELEN R. BUCKLEY* \\ Department of Microbiology and Immunology: Temple University School of Medicine. \\ Philadelphia. Pennsyltania 19140, USA
}

(Received 6 March 1984; revised 24 May 1984)

\begin{abstract}
The growth of four clinical strains of Paracoccidioides brasiliensis was investigated using the chemically defined medium of McVeigh and Morton. Emphasis was placed upon controlling conditions of inoculum preparation, age of inoculum used, and the homogeneity of samples used for analysis. The medium was evaluated for its ability to support growth of the yeast phase of $\boldsymbol{P}$. brasiliensis at $37^{\circ} \mathrm{C}$. Cultures were followed for $240 \mathrm{~h}$ and growth patterns were determined by measuring optical density, dry weight, nucleic acids and protein. The medium is excellent for growing the yeast phase of $P$. brasiliensis. The exponential phase lasted an average of $135 \mathrm{~h}$ and the stationary phase $72 \mathrm{~h}$; a decline began after $207 \mathrm{~h}$. This defined medium supports abundant growth of the yeast phase of $P$. brasiliensis and may thus prove useful in the preparation of yeastphase antigens.
\end{abstract}

\section{INTRODUCTION}

A comparison of growth patterns using different strains of the yeast form of Paracoccidioides brasiliensis isolated from patients with South American blastomycosis has been hampered by the lack of chemically defined media (Gilardi \& Loffer, 1962; Ramirez-Martinez, 1970, 1972; Lee $e t$ al., 1975). Most investigators studying this organism have chosen to study only a single parameter of growth, such as turbidity or nucleic acid production (Ramirez-Martinez, 1970, 1971 ; San-Blas \& Cova, 1975; Arango \& Restrepo, 1976; Restrepo \& Jiménez, 1980). Growth in complex media containing undefined ingredients has been studied; however, the results are not comparable (Ramirez-Martinez, 1970, 1972). It has been suggested that reproducibility of growth curves based on turbidimetric measurements is only possible when conditions such as inoculum age, sample homogeneity, and incubation conditions are rigorously controlled (Nickerson \& Edwards, 1949; San-Blas \& Cova, 1975). When studying $P$. brasiliensis the comparison of these parameters is difficult because the yeast phase does not readily grow in liquid media and forms clumps even when the conditions of growth include shaking.

Previous authors have reported success in growing the yeast form of $P$. brasiliensis in a modified McVeigh-Morton medium (Restrepo \& Jiménez, 1980). Measurements of turbidity with six isolates and viable cell counts with one isolate were used to produce growth curves. Preliminary studies in our laboratory showed the original formulation of McVeigh-Morton (MM) medium to be equally capable of supporting the growth of $P$. brasiliensis if care was taken to avoid precipitation of salts when preparing the medium. All the components of this medium are chemically defined, making it suitable for analysis of growth rates as well as for antigen production.

Here we describe a method for inoculum preparation and the determination of growth rates in MM medium, using four clinical isolates of $P$. brasiliensis. Growth rate was evaluated by measurements of optical density, dry weight, nucleic acids and protein.

Abbreviations: MM, McVeigh-Morton; PCA, perchloric acid. 


\section{METHODS}

Sirains and grow th conditions. Four human isolates of $P$. brasiliensis were studied. Three strains, Manco. Suarez, and MTC, were kindly supplied by Angela Restrepo, Corporacion de Investigaciones Biologicas, Colombia. The fourth strain. J79, was an isolate from Ecuador supplied by Robert Mandle. Thomas Jefferson University. Philadelphia. The mycelial cultures of these isolates were converted to the yeast form at $37^{\circ} \mathrm{C}$ on $\mathrm{MM}$ agar (McVeigh \& Morton, 1965). Every third day, blind subcultures were done onto a fresh agar slant (MM) until a typical pasty growth was seen. After $5 \mathrm{~d}$, the yeast cells from these isolates were transferred to a flask of liquid medium (MM) and grown at $37^{\circ} \mathrm{C}$ on gyratory shaker at 250 r.p.m. After $S \mathrm{~d}$ growth, the cultures were filtered through sintered glass funnels and the resultant slurry was homogenized in a tissue grinder until single-cell suspensions were obtained. These cells were added $\left(O D_{b}, 5=0.10\right)$ into 20 flasks containing the same medium. The flasks were incubated at $37^{\circ} \mathrm{C}$ on a gyratory shaker at 250 r.p.m.

Sampling, counts and dry weights. Samples for analysis were taken at time zero and then every $12 \mathrm{~h}$ for a total of $240 \mathrm{~h}$. At each time point, a single flask was removed for sampling. The first sample of $5 \mathrm{ml}$ was used for determination of $\mathrm{OD}_{\mathrm{e}}$. 5 . Readings were made in triplicate and the mean was recorded. Two samples of approximately $20 \mathrm{ml}$ were placed into sterile conical centrifuge tubes and centrifuged twice at $20000 \mathrm{~g}$ for $15 \mathrm{~min}$. The pellets were resuspended each time in distilled water. The cells then were resuspended in $5 \mathrm{ml}$ sterile distilled water and frozen at $-20^{\circ} \mathrm{C}$ for nucleic acid and protein determinations. An additional sample of approximately $20 \mathrm{ml}$ was removed for dry weight analysis. This sample was washed and pelleted as just described. The cells were resuspended in $5 \mathrm{ml}$ sterile water and filtered through a preweighed HA $0.45 \mu \mathrm{m}$ filter (Nalgene Sybron Corp., Rochester, NY, USA). The filters containing the organisms were dried by desiccation until three consecutive weighings showed no change in weight. Dry weight was recorded as $\mu \mathrm{g}$ per ml of sample. An additional sample of $1 \mathrm{ml}$ was used for cell counts. It was diluted $1: 2$ in $0.1 \%$ trypan blue and mixed by vortexing: duplicate cell counts were made in a haemocytometer and the mean value was recorded. Cell aggregates, when present, were counted as single cells.

Nucleic acid and protein determinations. Extractions for nucleic acids and protein were done by a modification of the procedure of Bhargava \& Halvorson (1971). The pellet of cells was washed once with $25 \%(\mathrm{v} / \mathrm{v})$ ethanol and twice with $10 \mathrm{ml}$ volumes of $70 \%$ ethanol. The cells were resuspended in a small volume of cold sterile water. To the chilled cell suspension $3 \mathrm{ml}$ cold $0.5 \mathrm{M}$-perchloric acid (PCA) was added and the mixture was incubated on ice for $15 \mathrm{~min}$. The cell suspension was centrifuged at 20000 and the supernatant discarded. The cell pellet was extracted twice with $1 \mathrm{ml} 0.5 \mathrm{M}$-PCA for $2 \mathrm{~h}$ at $37^{\circ} \mathrm{C}$; the combined supernatants from the two extractions were used for measurement of RNA. The cells were then resuspended and extracted twice with 3 to $4 \mathrm{ml} 0.5 \mathrm{M}$-PCA for $30 \mathrm{~min}$ at $70^{\circ} \mathrm{C}$ : the combined supernatants from these two extractions were used for measurement of DNA. The sediment was solubilized in $3 \mathrm{mI} I \mathrm{M}-\mathrm{NaOH}$ for $1 \mathrm{~h}$ at $60^{\circ} \mathrm{C}$ for measurement of protein.

DNA was assayed using a diphenylamine reagent with calf thymus DNA as a standard (Burton, 1956). RNA was colorimetrically determined by the orcinol method with yeast RNA as a standard (Drury, 1948). Protein determination was by the Lowry procedure with bovine serum albumin as a standard.

\section{RESULTS AND DISCUSSION}

The four clinical strains of $P$. brasiliensis tested showed balanced growth in the chemically defined MM medium. Despite differences in growth rates and peak levels of macromolecules produced, all the strains grew well in this medium, and three of them produced abundant growth. The use of a homogenized inoculum resulted in a less erratic pattern of growth, facilitating comparisons between strains. Three growth curves were obtained for each of the four isolates; mean values for two strains are presented in the figures. Data for all four strains are summarized in Table 1 . The optical density and dry weight values for strains Suarez and $\mathrm{J} 79$ are shown in Fig. 1. With all four strains, a regular pattern of growth was seen. Isolates J79, Manco and MTC had similar growth characteristics. The Suarez strain was a slow grower and failed to reach the optical densities achieved by the other three strains. In addition, a decline in $O_{6} D_{6}$ was never observed with this strain, despite the fact that a decline in dry weight occurred $204 \mathrm{~h}$ after initial inoculation. These differences were probably due to a brown pigment which was secreted into the medium during growth of the Suarez strain. To our knowledge, pigment production by the yeast phase of $\boldsymbol{P}$. brasiliensis has not previously been reported, perhaps because MM medium has seldom been used for studying growth of the yeast phase of $P$. brasiliensis.

The Suarez strain was also different in that its cell size was less than half that of the other strains $(8 \mu \mathrm{m}$ vs $20 \mu \mathrm{m})$. Despite this, however, its nucleic acid, dry weight and protein levels 
Table 1. Duration of different phases of grow'th of the four strains of P. brasiliensis

The times shown are hours from the start of incubation. None of the strains showed a discernible lag phase.

$\begin{array}{lccrr}\begin{array}{l}\text { Growth } \\ \text { phase }\end{array} & \text { Suarez } & \text { J79 } & \text { MTC } & \text { Manco } \\ \text { Exponential } & 0-96 & 0-132 & 0-156 & 0-156 \\ \text { Stationary } & 96-192 & 132-216 & 156-228 & 156-192 \\ \text { Decline } & 192-240 & 216-240 & 228-240 & 192-240\end{array}$

were similar to those of the other strains tested. To date, no investigations have been made concerning variability between strains of $P$. brasiliensis related to cell size. Various investigators studying the mycelial and yeast forms have noted the unstable growth curves obtained with the yeast form (Ramirez-Martinez, 1970; San-Blas \& Cova, 1975; Arango \& Restrepo, 1976); however, none has mentioned the relative cell size of the different strains tested.

There was no apparent lag phase in any of the organisms. This was attributed to the use of a homogenized inoculum which had already reached exponential phase when transferred to fresh medium. The range of time in the different stages of growth as determined by optical density and dry weight measurements is shown in Table 1 . The total length of the decline periods could not be calculated, since this study was terminated at $240 \mathrm{~h}$; however, all strains tested began to decline in growth after 8 to $9 \mathrm{~d}$.

Cell numbers as measured by haemocytometer proved to be unreliable and an inconsistent monitor of growth, so the data are not presented. This problem is related to the multiple budding behaviour of this organism. During vortexing, budding cells would detach from the main cell. It then became impossible to distinguish between daughter cells and the main cell, especially with the Suarez strain, where the size of the bud $(6 \mu \mathrm{m})$ was similar to that of the mother cell $(8 \mu \mathrm{m})$. To date, there is no evidence that detached buds form colonies when plated out, hence only the main cells must be considered in a count. San-Blas \& Cova (1975) found that counts of cell numbers after vital staining paralleled culture turbidity. However, other authors (Arango \& Restrepo, 1976; Restrepo \& Jiménez, 1980) have felt that colony counts on solid media are the only reliable method of obtaining an estimation of viable cell numbers using the yeast phase of $P$. brasiliensis, and our experience would support such a conclusion.

The RNA level of all four strains reached a maximum after 120 to $180 \mathrm{~h}$ of growth (Fig. $2 a$ ), followed by a rapid decrease which extended through the period of study. The rise in RNA reffected that seen in total protein for each of the four strains (Fig. 2b). The J79 and MTC strains yielded the highest maximum DNA level, whereas the maximum DNA level of the Suarez and Manco strains was one-half to one-third of that seen with the J79 and MTC strains. Data for the MTC and Manco strains are shown in Fig. 2(c). Despite these differences in nucleic acid levels, all four strains produced high levels of protein, maxima occurring between 132 and $180 \mathrm{~h} \mathrm{(5.5} \mathrm{to}$ $7.5 \mathrm{~d})$ of growth.

Changes in nucleic acid levels, particularly DNA, were easily seen with all four strains. This is in contrast to an earlier report where DNA content ( $\mu \mathrm{g}$ per $\mathrm{mg}$ dry wt) remained almost unchanged over a $10 \mathrm{~d}$ growth period, despite increases in RNA and dry weight during the same period (Ramirez-Martinez, 1970). The maximum amount of DNA was observed on the first day, even though dry weight peaked between the fourth and fifth day of growth. This may have been due to the harsher methods that Ramirez-Martinez used for extraction, which can result in protein products that interfere with the methods used for nucleic acid detection. In addition, the holding of our samples and extracts at $-20^{\circ} \mathrm{C}$ until determinations were performed prevented the loss and underestimation of nucleic acids. Since the yeast phase of $P$. brasiliensis is multinucleate, a change in overall DNA per cell grown over a $240 \mathrm{~h}$ period would be expected.

The doubling times in terms of dry weight, $\mathrm{OD}_{675}$, nucleic acids and protein are shown in Table 2. For all four strains, the doubling time ranged between 24 and $35 \mathrm{~h}$, averaging approximately $29 \mathrm{~h}$. 


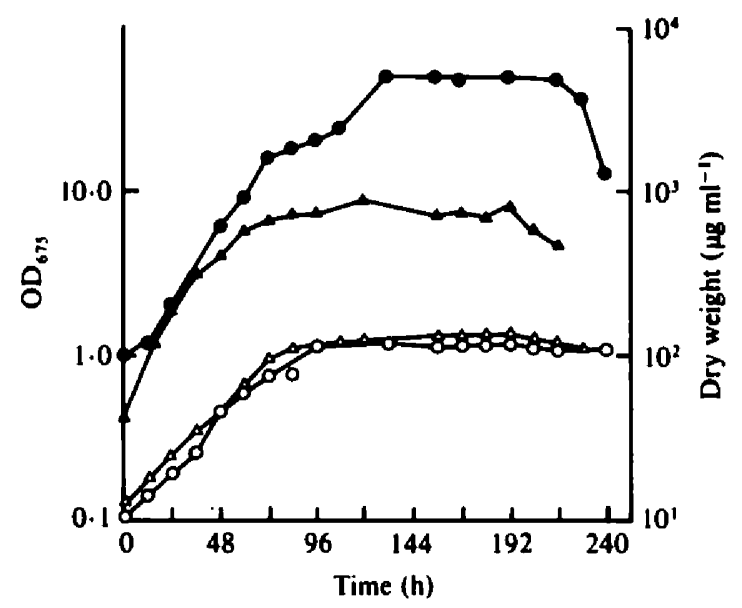

Fig. 1.

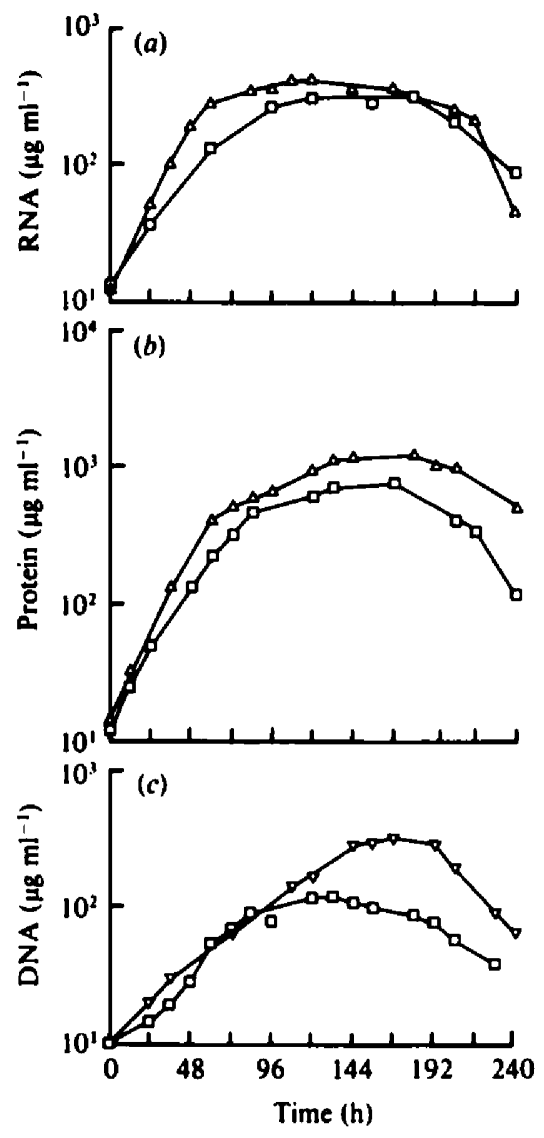

Fig. 2

Fig. 1. Optical density and dry weight curves for strains $\operatorname{Suarez}(\Delta, \Delta)$ and $\mathrm{J} 79(0, \Theta)$ of $P$. brasiliensis grown in MM medium. Each point represents the mean of values for three cultures. For cach culture, optical density readings (filled symbols) were taken in triplicate (means are shown), and dry weight (open symbols) was determined on a single sample.

Fig. 2. Production of (a) RNA, (b) protein and (c) DNA by strains of $P$. brasiliensis during growth in MM medium. The values plotted are means of three $(b, c)$ or of at least two $(a)$ independent determinations done on each of three cultures. Strains: $\triangle$, Suarez; $\square$, Manco; $\nabla$, MTC

Table 2. Doubling times (h) for the four strains of P. brasiliensis

$\begin{array}{lllll}\text { Property } & \text { J79 } & \text { Manco } & \text { MTC } & \text { Suarez } \\ \text { Dry weight } & 28.8 & 27.1 & 28.4 & 29.3 \\ \text { RNA } & 29.2 & 24 & 22.4 & 12 \\ \text { DNA } & 31.2 & 29.2 & 26.4 & 26.4 \\ \text { Protein } & 24 & 21.6 & 14.4 & 12 \\ \text { OD }_{\text {b75 }} & 35 & 33.4 & 34.6 & 35.7\end{array}$

For investigators who prefer working with exponentially growing cells, MM medium is ideal. With all four strains, the yeast phase remained in the exponential phase of growth for at least $120 \mathrm{~h}$. Despite some differences in methodology, our results may be compared with those of Restrepo \& Jiménez (1980), using a modified MM medium. Their study showed an exponential phase of $108 \mathrm{~h}$, a stationary phase of approximately $84 \mathrm{~h}$, and a relatively abrupt decline after 
$192 \mathrm{~h}$. Our corresponding values were $135 \mathrm{~h}, 72 \mathrm{~h}$ and $207 \mathrm{~h}$. This is encouraging, since the media used in the two experiments are very similar, varying only in the concentration of vitamins. Since MM medium supports abundant growth, the changes in mass and the total protein yield are very high, and this medium is to be recommended for those who wish to produce antigens which are predominantly protein in composition. Since it supports growth of the yeast phase and is chemically defined, this medium or its modified form should be of use in the preparation of reproducible yeast-phase antigens and for examining the effects of physical and chemical factors on the growth of $P$. brasiliensis.

We thank Gregory Harvey for his editorial assistance, and Nancy L. Reichenbach for her advice and technical assistance during preparation of the graphs.

This work was supported by Public Health Service training grant for Medical Mycology AI 07141 from the National Institutes of Health.

\section{REFERENCES}

ARANGo, M. \& Restrepo, A. (1976). Determination of the growth curves of the mycelial and yeast forms of Paracoccidioides brasiliensis. Mycopathologia 59, 163169.

Bhargava, M. M. \& Halvorson, H. O. (1971). Isolation of nuclei from yeast. Journal of Cell Biology 49. 423-429.

Burton, K. (1956). A study of conditions and mechanism of diphenylamine reaction for the colorimetric estimation of DNA. Journal of Biochemistry 62, 315-323.

DRURY, H. F. (1948). Identification and estimation of pentoses in the presence of glucose. Archives of Biochemistry 19, 455-460.

Gilard, G. L. \& LOFFER, N. C. (1962). Nutritional studies on the yeast phase of Blastomyces dermatitidis and B. brasiliensis. Joumal of Bacteriology 83, 219227.

Lee, K. L., Reca, M. E. \& Campbell, C. C. (1975). Amino acid synthetic media for fungal pathogens based on aminopeptidase specificities: $\boldsymbol{H}$. capsulatum, B. dermatitidis, $\boldsymbol{P}$. brasiliensis, and $\boldsymbol{C}$. neoformans. Sabouraudia 13, 142-147.

McVeioh, I. \& Monton, K. (1965). Nutritional studies of Histoplasma capsulatum. Mycopathology 25. 294 308.
Nickerson, W. J. \& Edwards, G. A. (1949). Studies on the physiological basis of morphogenesis in fungi. I. The respiratory metabolism of dimorphic pathogenic fungi. Journal of General Physiology 33, 41-55.

RAMfrez-MartiNez, J. R. (1970). Growth curves and nucleic acids content of mycelial and yeast like forms of Paracoccidioides brasiliensis. Mycopathologia et mycologia applicata 41, 203-210.

Rauírez-Martinez, J. R. (1971). A comparative study of ribonucleic acid species in yeast like and mycelial forms of Paracoccidioides brasiliensis. Sabouraudia 9, 157-163.

RAMfrez-Martinez, J. R. (1972). Growth and physiological characteristics of $\boldsymbol{P}$. brasiliensis. In Proceedings of a Symposium on Paracoccidioidomycosis, pp. 13-20. Washington, DC: Pan American Health Organization (Scientific Publication no. 254).

Restrepo, A. Jimtnez, B. E. (1980). Growth of Paracoccidioides brasiliensis yeast phase in a chemically defined culture medium. Joumal of Clinical Microbiology 12, 279-281.

San-Blas, F. COVA, L. J. (1975). Growth curves of the ycast like form of Paracoccidioides brasiliensis. Sabouraudia 13, 22-29. 